\title{
Are mothers of young children more likely to be self-employed? The case of Sweden
}

\author{
Pernilla Andersson Joona $\mathbb{D}^{1}$
}

Received: 25 August 2015 / Accepted: 12 August 2016 / Published online: 28 September 2016

(C) Springer Science+Business Media New York 2016

\begin{abstract}
Previous studies, mostly from Anglo-Saxon countries, find a positive correlation between the presence of young children in the household and selfemployment probabilities among women. This has been seen as an indication of women with young children choosing self-employment as a way of balancing work and family commitments. This paper studies the relationship between children and female self-employment in a country with family friendly policies and a generous welfare system: Sweden. The initial hypothesis is that we will not find evidence of a positive effect of children on self-employment among Swedish women since there are other institutions in place aiming at facilitating the combination of work and family. Using Swedish register data for the period 2004-2008 we do, however, find that the presence of young children increases the probability of choosing selfemployment also among Swedish women. The effect is strongest for women with very young children, 0-3 years of age. These results also hold in a panel data model that takes individual unobserved heterogeneity into account. We also analyze timeuse data and find, contrary to what has been found in many other countries, that selfemployed women spend more, or as much, time on market work than wage-earning women. This raises doubts about whether women in Sweden chose self-employment as a way of balancing work and family commitments.
\end{abstract}

Keywords Self-employment $\cdot$ Fertility $\cdot$ Work $\cdot$ Family

JEL Classification $\mathrm{L} 26 \cdot \mathrm{J} 22 \cdot \mathrm{J} 13$

Pernilla Andersson Joona

Pernilla.andersson.joona@sofi.su.se

1 Swedish Institute for Social Research, Stockholm University, Stockholm S-106 91, Sweden 


\section{Introduction}

It has been argued that women choose self-employment as a way of balancing work and family commitments, in particular if there are young children living in the household. The presence of children increases the amount of household work at the same time as the parents' demand for flexible scheduling increases. Self-employment is assumed to increase flexibility regarding when and where the work is performed and self-employment also involves a higher degree of control and self-determination than what wage-earning employment does. Previous studies, mostly from Anglo-Saxon countries, find a positive correlation between the presence of young children in the household and self-employment probabilities among women (Boden 1996; Budig 2006; Hundley 2000; Lombard 2001; Wellington 2006). This has been interpreted as evidence of women choosing self-employment as a way to balance work and family. Boden (1999) using survey data from the United States report that in particular women with young children are more likely than men to state that they become self-employed to increase flexibility and for family-related reasons. This is also in line with the findings of Carr (1996). Related studies using time-use data find that self-employed women spend more time on household work than wage-earning women and less time on market work (Gurley-Calvez et al. 2009; Craig et al. 2012).

There are no previous studies investigating this hypothesis for Sweden where the labor market is structured in a very different way than, for example, the United States. There are reasons to believe that Swedish women do not choose self-employment in order to balance work and family; there are other institutions in place aimed at facilitating the combination of work and family: large-scale publically subsidized child care, a generous parental leave system with built-in incentives for fathers to take more parental leave ${ }^{1}$, and the right for parents with children up to 8 years to work part time. In an international comparison, female self-employment rates in Sweden are low while female labor force participation is high, part-time work is high, and fertility levels are high. ${ }^{2}$ Taken together, it seems plausible that Swedish women manage to combine work and family without choosing self-employment to a very high extent. Rønsen (2014) discusses the relationship between children and self-employment among Norwegian women in a similar way: the extra working time associated with being self-employed should outweigh the flexibility and self-autonomy associated with being self-employed in a welfare-state, such as Norway, with a good supply of state-sponsored child care. Rønsen (2014) does, however, find indications of a positive association between the presence of young children (up to 11 years of age) and female self-employment also in Norway. Using survey data with information on working hours, she also reports that self-employed women on average spend more time on market work than wage-earning women do.

\footnotetext{
${ }^{1}$ Examples of this are two so-called "daddy-months" that cannot be transferred to the mother, a higher replacement rate than in the public health insurance, and a bonus paid to couples who share their parental leave equally.

2 There are other macro-level factors that influence self-employment rates in a country and may explain country differences. Since also male self-employment rates in Sweden are lower than in many other countries, this suggests that (other) institutions also matters. These could, e.g., be: per capita gross domestic product, the size of the public sector (Torrini 2005), taxes (Davis and Henrekson 1999; Fölster 2002), and unemployment levels (Blanchflower 2000).
} 
In a cross-country comparison, Noseleit (2014b) tests the hypothesis that the female self-employment share is lower in countries with better child care provision. The hypothesis is supported and in addition it is found that women who become selfemployed in countries with better child care availability tends to have higher education and more often hire employees.

In this paper Swedish register data for the total Swedish population covering the period 2004-2008 is used, and both pooled cross-sectional models and fixed-effect models are estimated to analyze the effect of young children in the household on selfemployment probabilities. It is found that the presence of young children increases self-employment probabilities also among Swedish women. The effect is strongest for women with very young children, 0-3 years of age, and the effect is decreasing with the age of the children. A positive effect of having children on self-employment probabilities is also found for men but here the effect is strongest for the presence of slightly older children.

Should this result be interpreted as that women in Sweden chose selfemployment to balance work and family? Or is there an alternative explanation for why women with young children become self-employed? ${ }^{3}$ To discuss this further we look at how much time self-employed women spend on market and household work compared to wage-earning women. If women choose self-employment as a way to balance work and family we would expect that they spend less time on market work and more time on household work compared to wage-earning women. Hundley (2000) argues that self-employment are not subject to some of the constraints of organizational employment; he assumes that there is a lower bound defined by the minimum contribution of the worker in organizational employment and an upper bound defined by the ability of organizations of rewarding very skilled employees. Due to the lack of primarily the lower bound in self-employment, it will be easier for the self-employed to adjust their time spent on market and household work if family responsibilities increase. Having the US labor market in mind, he further argues that self-employed women will work fewer market hours and more housework hours compared to their organizational employed counterparts, while the opposite will be true for self-employed men. Previous studies for Sweden and several different data sources with information about how workers divide their time between market and household work show that self-employed women in Sweden spend more, or as much, time on market work than wage-earning women and there are no significant differences in the amount of time spent on household work. This raises doubts about whether women in Sweden choses self-employment as a way to balance work and family. Instead, it seems plausible that women who choose self-employment while the children are young in fact are women with strong preferences for market work.

In addition to analyzing time-use data, differences in number of days of parental leave between self-employed and wage earners are also analyzed. If women chose self-employment to balance work and family, we would expect that they take more parental leave compared to wage earners. Using administrative data, we find that the

\footnotetext{
3 Based on the results from an analysis of parental leave and self-employment in Sweden, Anxo and Ericson (2015) draw the conclusion that women who have stronger commitments to paid work are more prone to choose self-employment.
} 
group of self-employed appears to be very heterogeneous; self-employed mothers are more likely to take no, or very short, parental leave when the children are very young but among those who take some parental leave, self-employed mothers take on average more days of parental leave than wage-earning mothers.

This paper makes several contributions to the existing literature. First, results presented in previous research are mainly based on data from Anglo-Saxon countries while this study uses data for Sweden. The Swedish labor market is organized in a very different way than in Anglo-Saxon countries and it is of great interest to see if the results for Sweden are consistent with findings for other countries. One exception to previous research is Rønsen (2014) for Norway but this study is interesting for comparison. Second, in the present study register data for the period 2004-2008 covering the whole Swedish population is used. Most previous studies are based on rather small samples, and are often restricted to smaller groups, e.g., married white women, and cover earlier time periods. Third, the association between selfemployment and the presence of young children in the household is further discussed by relating our findings to what is known about how self-employed and wage earners divide their time between market and household work and to differences in days of parental leave between self-employed and wage earners.

Relating the results presented in this paper to previous results for other countries, we can see that the demand for self-employment increases if there is young children in the household, in spite of large differences in labor market institutions. It is, however, possible that the motives to choose self-employment among women with young children differ across countries. Differences between countries in time spent on market work compared to wage earners indicate that there are such differences. Also taking differences in the female self-employment share across countries into account, this could mean that self-employment is a more commonly adopted strategy among women in countries with less child care provision and a solution chosen by a more selected group of women in countries like Sweden. It is, however, also possible that cross-country differences in female self-employment mostly could be attributed to differences in self-employment among women without dependent children and that the demand for self-employment among mothers of young children is equal across countries in spite of differences in institutions.

The remainder of the paper is structured as follows. In Section 2 previous research is discussed in more detail, in Section 3 the data, variables, and the econometric approach are described, in Section 4 the results are presented, and in Section 5 the findings are related to differences in time spent on market work between selfemployed and wage earners and differences in the use of parental leave. Finally, Section 6 summarizes and concludes the paper.

\section{Previous research}

Using data from the United States, Wellington (2006) examines the hypothesis that married women are increasingly choosing self-employment as a strategy to balance family and career. In the econometric analysis, the author estimates the effect of children on the probability of being, and becoming, self-employed. This is estimated both using cross-sectional and longitudinal data. It is found that the presence of young children 
increases the probability of being self-employed but the impact of children does not appear to have increased over time. The conclusion that is drawn is that mother's increased labor force participation comes at a direct cost of time spent with children.

Lombard (2001) uses similar data and also finds that the presence of children increases the likelihood of self-employment. Here it is assumed that women with children have a higher demand for flexible scheduling and that this is more easily attained when being self-employed.

In an article from 1996, Boden hypothesize that fertility, defined as having at least one child under the age of 6 , will have a positive impact on self-employment entry. This article uses the same type of data as the two abovementioned, the Current Population Survey for the United States. Boden finds a positive influence of fertility of female self-employment.

Budig (2006) differentiate between non-professional and non-managerial selfemployment, on the one hand, and professional and managerial self-employment, on the other hand, when analyzing the effects of family structure on self-employment. This is tested using survey data (the NLYS) for the United States and it is found that children increases women's non-professional self-employment but has no effect on professional self-employment. The interpretation suggested for these results is that the demand for increased flexibility and more control over work schedules is lower among women in professional wage employment since many occupations of this type already offer more flexibility. An alternative explanation is that women in professional wage employment have less family responsibilities, having fewer children compared to women in non-professional employment could be a sign of this.

Noseleit (2014a) analyzes the relation between fertility and self-employment using data from the European Social Survey. The focus of this article is on the direction of causality between self-employment and fertility, something that many previous studies have failed to account for. Most studies are interested in the effect of fertility, or the presence of children, on self-employment. But one could also argue that the direction of causality is reversed, i.e., that self-employment will cause women, and perhaps also men, to have more children. One argument for this is that self-employed individuals want to maximize the probability that one of their children can take over the business and therefore have more children than employees (Broussard et al. 2015). To establish the direction of causality, Noseleit (2014a) uses instrument variable techniques and instrument fertility by parents' preferences for a mixed sibling-sex composition, as has been done by Angrist and Evans (1998) and by instrumenting self-employment with the regional share of employees working in small businesses. The IV estimates indicate that fertility has a positive effect on selfemployment while he finds no evidence of that the reverse should be true, i.e., that self-employment leads to higher fertility rates among women. An exception is, however, that he finds that among women between 31 and 45 years of age, selfemployment has a positive effect on fertility.

Hundley (2000) analyzes male/female earnings differentials in self-employment using survey data from the United States. He argues that organizational employment is constrained by both lower bounds (on acceptable employee contribution) and upper bounds (on employee rewards) which self-employment is not. If there are changes in the demands for household production associated with marriage and children, self-employed women could respond to these changes more easily than 
organizational employed women since there is no lower bound on employee contribution for the self-employed. However, this might of course result in lower incomes for self-employed woman. In more general terms, he argues that due to the lack of constraints for the self-employed it is likely that some self-employed will participate more intensively in either household or market work. As a consequence, self-employed married women will work fewer market hours and more housework hours and self-employed men will work more market hours and fewer housework hours compared to organizational employed women and men.

This prediction is consistent with what is found in studies using time-use data: self-employed women tend to spend less time on market work than wage-earning women and more time on household work and/or child care (see Gurley-Calvez et al. 2009 for the United States; Craig et al. 2012 for Australia). A study for Spain finds differences in time spent on market work where self-employed women spend less time, but do not find any significant difference in time spent on child care between self-employed and wage-earning women (Gimenez-Nadal et al. 2012 for Spain). Gutiérrez-Doménche (2010) does, however, find that self-employed fathers and mothers in Spain spend less time with their children than wage earners in the public and the private sector. It has also been found that self-employed women more often work during non-standard work hours, i.e., during evenings and weekends (Gimenez-Nadal et al. 2012; Lombard 2001).

These results are, however, not entirely consistent with what has been found for Sweden. Mångs (2013) finds that self-employed women, with and without young children (0-3 years), spend more hours on market work than wage-earning women. Johansson Sevä and Öun (2014) find that self-employed women with employees spend more time on market work compared to both self-employed without employees and regularly employed women. They also find that self-employed women without employees are more likely than regularly employed to state that they experience balance between family and work commitments, while self-employed with employees are less likely of experiencing work-family balance and more likely of experiencing work to family conflict. As is shown below, a majority of selfemployed females in the entire workforce have no employees, and also in the sample used in Johansson Sevä and Öun (2014) the majority has no employees.

Using data from the European Social Survey, Nordenmark et al. (2012) find that self-employed women experience a significantly higher level of work-life balance than wage-earning women, while self-employed men experience a similar level of work-life balance as employed men. These are interesting results but since they use data for all 26 countries included in the survey we do not know whether the correlations are found in all countries or whether the pattern in Sweden differs from those in other European countries.

\section{Data and econometric analysis}

\subsection{Data and variables}

The main analysis is based on individual-level register data from the employment register at Statistics Sweden covering the period from 2004 to 2008. These data are 
collected mainly for administrative purposes and includes information on, e.g., employment status (wage earners, self-employed, or not employed) in November each year, age, marital status, number of children residing in the household, education, country of birth, and place of residence. An individual is defined as selfemployed with an unincorporated firm if the largest source of income during November is from self-employment. The self-employment income is however adjusted with the factor 1.6 since the self-employed in general report lower incomes. Self-employed with incorporated firms receive a wage income, just as regular employees, since they are employed in their own firm. The self-employed, as they are defined here, could both be owners of unincorporated or incorporated firms and of firms both with and without employees. The incorporated firms included are, however, only firms with ten or fewer stockholders. The firms can be active in all industries and include everything from farmers or carpenters to lawyers and physical therapists. This means that the group of self-employed is heterogeneous in terms of education, industry, and occupation. In Table 2 some descriptive statistics is presented and we see that almost $75 \%$ of the firms run by self-employed are unincorporated firms and almost $70 \%$ are solo entrepreneurs. Hence, even if it is a heterogeneous group, the large majority have similar traits in terms of corporate form and size. If we look at industry we see that over $40 \%$ are in services ("financial and business services" and "personal and cultural services"). The third largest group are those in "retailing and communications".

In the analysis the sample includes all women aged 16-64 years of age independent of employment status, i.e., the dependent variable in the main regression is 1 if an individual is working as self-employed and 0 otherwise. Since individuals who are students, unemployed, on sick leave, or outside the labor force are included in the study we will also consider transitions from these states into self-employment in the fixed-effect analysis.

The main independent variable of interest in this paper is a measure of fertility, or the presence of children in the household. The register includes information on the number of children in different age ranges living in the household, i.e., the exact age of each child is not known. There are several ways of controlling for the number and the age of the children in the regression analysis. Different definitions have been tried but the main results are invariant to the definition used. Results from a regression where we control for the number of children in all different age ranges: 0-3 years, 4-6 years, 7-10 years, 11-15 years, 16-17 years, and 18 years or above are presented.

To be able to better understand and interpret our results on the relationship between children in different age ranges and self-employment, some descriptive results using aggregate data from the Harmonized European Time Use Survey (HETUS) are also presented. These data were collected within a project supported by Eurostat and it is possible to calculate user defined, comparable statistical tables on the organization and activities of everyday life in 15 European countries. ${ }^{4}$ The Swedish data originates from the time-use survey conducted by Statistics Sweden in 2000/2001.

\footnotetext{
4 To read more about HETUS, see https://www.h2.scb.se/tus/tus/.
} 
To further illustrate how self-employed and wage earners divide their time between market and household work, individual-level data from the Swedish Level of Living Survey for year 2000 is also used. These data are from a survey that has been conducted among a random sample of 1/1000 of the Swedish population. The respondents are asked questions about their living conditions in several areas. The drawback of this data is that it includes very few self-employed women.

\subsection{Econometric analysis}

Panel data for the period 2004-2008 is used and both pooled cross-sectional models (equation 1) and models that include individual time fixed effects (equation 2) are estimated. Our key independent variables of interest are the number of children living in the household in different age ranges (0-3 years, 4-6 years, 7-10 years, 11-15 years, 16-17 years, and 18 years or above). The vector $\mathbf{X}$ includes controls for: age, age squared, being married, education, industry, country of birth, county of residence, and year. The regressions are estimated separately for women and men, and we focus on the results for women.

$$
S E_{i t}=\alpha+\beta_{1} \text { Child0_3 } 3_{i t}+\beta_{2} \text { Child4_6 } 6_{i t}+\ldots+\beta_{6} \text { Child } 18_{i t}+\delta X_{i t}+\varepsilon_{i t}
$$

It should be stressed that the $\beta$-coefficients in equation 1 are not measures of the causal effect of the number of children on self-employment. In this model the comparison is made between individuals who differ in their preferences for the number of children and self-employment, two factors that are outcomes of decisions that are not exogenous to each other. To try do address this problem individual fixed effects are included in equation 2 . This is assumed to be a time fixed effect that varies between individuals but is constant over time, which for example could be preferences for employment form and family formation or family size. Since this model is estimated using panel data methods, the comparison becomes intra-personal rather than inter-personal, i.e., we compare the same individual with herself over time. Put simply, the impact of a change in the number of children in different age ranges on the change on employment status to and from self-employment is estimated. More formally, the model that is estimated is specified in equation 3, where all variables are expressed as the value of the variable for individual $i$ at time $t$ and its deviation from the mean calculated over all years for this individual.

$$
\begin{aligned}
& S E_{i t}=\alpha+\beta_{1} \text { Child0_3 } 3_{i t}+\beta_{2} \text { Child4_ } 6_{i t}+\ldots+\beta_{6} \text { Child } 18_{i t}+\delta X_{i t}+\mu_{i}+\varepsilon_{i t} \\
& S E_{i t}-\overline{S E_{i}}=\alpha+\beta_{1}\left(\text { Child0_3 }_{i t}-\overline{\text { Child } 0 \__{-}}\right)+\beta_{2}\left(\text { Child4 }_{-} 6_{i t}-\overline{\text { Child4 }_{-} 6_{i}}\right)+\ldots
\end{aligned}
$$

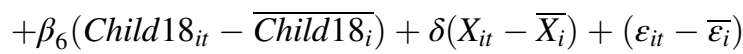

The dependent variable is a dichotomous variable taking the value 1 if the individual is self-employed and 0 if the individual is not self-employed. The models are first estimated using a linear probability model. This has the advantage that the interpretation of the coefficients is simple: each additional child in a certain age range increases or decreases the probability of being self-employed by a certain percentage point. Using this model there is, however, a risk that it will yield predicted 
probabilities outside the range of $0-1$. For this reason I also estimate both pooled cross-sectional and panel regressions using the non-linear logit model. To account for individual fixed effects in the logit model, so-called conditional fixed-effect models are also estimated (Chamberlain 1980, 1984; Maddala 1987). In this model, we condition on that there has been a change in the dependent variable between two time periods. Individuals who do not change state between two time periods are not included in the regressions, since they do not contribute to the likelihood function (Maddala 1987). As a consequence, this model uses substantially fewer observations than the other models.

In the Appendix we also present the results from a multinomial logit model with three outcome states: wage employment, self-employment, and non-employment. This model will tell us how the presence of children affects the choice between selfemployment and wage employment, and the choice between self-employment and non-employment.

\subsection{Descriptive statistics}

The main purpose of this study is to estimate the effect of the presence of children in the household on the probability of being self-employed. As a descriptive exercise self-employment rates among different groups of employed women are presented in Table 1. We present the self-employment share both among all women and conditional on employment. The sample is divided into eight groups depending on whether there are children living in the household, the age of the children, and the age of the women. The first group includes women who are older than 41 years old or younger and with no children living in the household. The last group includes women who are older than 41 years and with no children living in their household. The groups in between are women in all different age ranges with children in different age ranges living in the household. The groups are not mutually exclusive since women can have children in different age spans. For example, a woman can have one child in the age range $0-3$ and one child in the age range $4-6$. Since there is a positive correlation between self-employment and age, and also between the age of

Table 1 Self-employment rate (\%) and age of the children in the household 2008, women

\begin{tabular}{lll}
\hline & $\begin{array}{l}\text { Self-employment } \\
\text { among all } \\
\left(N_{\mathrm{SE}} / N_{\mathrm{All}}\right)\end{array}$ & $\begin{array}{l}\text { Self-employed, } \\
\text { conditional on } \\
\text { employment } \\
\left(N_{\mathrm{SE}} / N_{\mathrm{Emp}}\right)\end{array}$ \\
\hline No children (in the household) and 41 years old or below & 2.1 & 2.5 \\
Children 0-3 years & 3.3 & 4.0 \\
Children 4-6 years & 4.0 & 4.6 \\
Children 7-10 years & 4.3 & 5.0 \\
Children 11-15 years & 4.1 & 4.9 \\
Children 16-17 years & 3.0 & 3.9 \\
Children above 18 & 3.6 & 4.3 \\
No children (in the household) and older than 41 years & 5.5 & 7.0 \\
\hline
\end{tabular}


the children and the age of the mother, it is difficult to separate between the effect of the age of the mother and the age of the children on self-employment. This will, however, be dealt with more carefully in the regression analysis. Table 1 shows that self-employment is lowest among women 41 years or younger with no children and highest among women with no children but who are older than 41 . For women with children up to 17 years there appears to be an inverted u-shaped relation between the age of the children and self-employment with a peak in the self-employment rate among mothers with children between 7 and 10 years.

In Table 2 descriptive statistics for self-employed, wage earners, and those in nonemployment in 2008 are presented. Self-employed women are on average almost 8 years older than wage-earning women. The age difference is reflected in differences in marriage rates and fertility rates when studying the whole group of self-employed women; a substantially higher share of self-employed women are married and they have fewer children in all age groups living in their household. A higher share among the self-employed have relatively low education, not more than upper secondary school, while a lower share have university education. The distribution over sector is also presented and it is very different among wage earners and self-employed. The largest group of wage-earning women is employed in the health care sector, $27 \%$, while only $7 \%$ of the self-employed are active in this sector. We also find the same pattern regarding the educational sector. The self-employed are instead predominately located within "personal and cultural services" and "financial and business services". Lastly, annual labor income, both excluding and including transfers, are presented and we find that the self-employed on average have lower incomes than wage earners.

Those in non-employment are a very heterogeneous group. This group includes, as is shown in Table 2, students, unemployed, those on parental leave, in early retirement, and lastly a residual category. The largest group are those in early retirement, a group that can be expected to re-enter the labor market to a very low extent. Those in education are the third largest group. The mean age is the same as for wage earners but the variation is substantially higher. A much higher share have very low education and a substantially higher share than among wage earners and the self-employed are foreign born. Women in this group are less likely to have children in all age groups, except in the youngest, and they have on average fewer children living in their household compared to other groups. In sum, the group of nonemployed does not primarily consists of stay-at home mums or housewives. It is a heterogeneous group where one group are young enrolled in education and one group is older and are essentially no longer active on the labor market.

In the multivariate analysis we also estimate fixed-effects regression in which the estimates are identified by individuals for whom there is a changes in the variables. Therefore, it can be of interest to look at transitions into self-employment and how it is correlated with changes in the age group of the children. Hence, in Table 3 we present transitions into self-employment among women when they have their first child and when their children make transitions into different age groups. This is compared to transitions into self-employment among women who do not get a child or whose children do not make a transition into a higher age group. Transitions are in general low. The year-to-year transitions into self-employment is at most $1.10 \%$ and the lowest transition rate is $0.67 \%$. The general pattern is, however, that transitions 
Table 2 Descriptive statistics, selected variables 2008

\begin{tabular}{|c|c|c|c|}
\hline & Wage earners & Self-employed & Non-employed \\
\hline \multirow[t]{2}{*}{ Age (SD) } & 39.9 & 47.1 & 39.9 \\
\hline & $(13.7)$ & $(11.1)$ & $(16.5)$ \\
\hline Married & 40.8 & 58.3 & 37.6 \\
\hline \multicolumn{4}{|l|}{ Number of children in the household } \\
\hline Total & 1.071 & 1.004 & 0.69 \\
\hline $0-3$ years & 0.15 & 0.13 & 0.16 \\
\hline $4-6$ years & 0.11 & 0.11 & 0.09 \\
\hline $7-10$ years & 0.14 & 0.15 & 0.11 \\
\hline $11-15$ years & 0.22 & 0.23 & 0.19 \\
\hline $16-17$ years & 0.14 & 0.11 & 0.19 \\
\hline \multicolumn{4}{|l|}{ Education (\%) } \\
\hline \multicolumn{4}{|l|}{ Primary school less than 9 years } \\
\hline Primary school $9(10)$ years & 11.8 & 10.0 & 27,8 \\
\hline Upper secondary 2 years or less & 22.3 & 26.0 & 22,1 \\
\hline Upper secondary more than 2 years & 23.1 & 23.9 & 12,9 \\
\hline Higher education less than 3 years & 15.6 & 15.7 & 8,8 \\
\hline Higher education 3 years or more & 23.6 & 19.2 & 9,0 \\
\hline Postgraduate education & 0.7 & 0.5 & 0,3 \\
\hline Missing information & 0.4 & 0.5 & 8,4 \\
\hline Born in Sweden & 86.7 & 84.8 & 64.0 \\
\hline \multicolumn{4}{|l|}{ Industry $(\%)^{\mathrm{a}}$} \\
\hline Unknown & 1.5 & 11.3 & \\
\hline Agriculture & 7.6 & 7.2 & \\
\hline Manufacturing & 0.5 & 4.4 & \\
\hline Construction & 1.1 & 1.8 & \\
\hline Retailing and communication & 11.7 & 14.8 & \\
\hline Financial and business services & 13.5 & 21.2 & \\
\hline Education & 15.9 & 2.3 & \\
\hline Health care & 27.4 & 7.4 & \\
\hline Personal and cultural services & 4.6 & 21.3 & \\
\hline \multicolumn{4}{|l|}{ Characteristics of the firm } \\
\hline Limited liability firm & & 25.6 & \\
\hline Solo entrepreneur ${ }^{\mathrm{b}}$ & & 68.2 & \\
\hline Total annual labor income (SEK) & 210,056 & 164,610 & 941 \\
\hline Total annual labor income (incl. transfers) (SEK) & 221,400 & 172,21 & 990 \\
\hline \multicolumn{4}{|l|}{ Status among the non-employed } \\
\hline Education & & & 23.4 \\
\hline Unemployed & & & 3.1 \\
\hline Parental leave & & & 7.7 \\
\hline Early retirement & & & 35.9 \\
\hline Other & & & 29.9 \\
\hline Number of observations & $2,304,762$ & 114,840 & 505,188 \\
\hline
\end{tabular}

\footnotetext{
a The industries "production of energy" and "public administration" are not shown due to a smaller share than $0.1 \%$ of self-employed

${ }^{\mathrm{b}}$ Information on number of employees is missing for $4.7 \%$ of the self-employed in 2008
} 
Table 3 Transitions into selfemployment among women $(\%)$
Annual transitions into self-employment $(\%)$
$\mathrm{SE}_{\mathrm{t}-1}=0$ \& Child0_3 $3_{\mathrm{t}-1}=0$

$\mathrm{SE}_{\mathrm{t}}=1$ \& Child0 $-3_{\mathrm{t}}=1 \quad 0.89$

$\mathrm{SE}_{\mathrm{t}}=1 \&$ Child0 $-3_{\mathrm{t}}=0 \quad 0.67$

$(\mathbf{N}=27,230)$

$\mathrm{SE}_{\mathrm{t}-1}=0$ \& Child4-6 $\mathrm{t}_{\mathrm{t}-1}=0$

$\mathrm{SE}_{\mathrm{t}}=1 \&$ Child $4-6_{\mathrm{t}}=1 \quad 1.10$

$(\mathbf{N}=2911)$

0.75

$(\mathbf{N}=39,909)$

$\mathrm{SE}_{\mathrm{t}-1}=0$ \& Child7-10 $\mathrm{t}-1=0$

$\mathrm{SE}_{\mathrm{t}}=1$ \& Child7 $-10_{\mathrm{t}}=1 \quad 1.07$

$(\mathbf{N}=2442)$

0.78

$(\mathbf{N}=44,604)$

$\mathrm{SE}_{\mathrm{t}-1}=0$ \& Child11-15 $\mathrm{t}-1_{1}=0$

$\mathrm{SE}_{\mathrm{t}}=1 \&$ Child $11-15_{\mathrm{t}}=1 \quad 1.04$

$(\mathbf{N}=2431)$

0.84

$(\mathbf{N}=48,641)$

$\mathrm{SE}_{\mathrm{t}-1}=0$ \& Child16-17 $\mathrm{t}-1_{\mathbf{1}}=0$

$\mathrm{SE}_{\mathrm{t}}=1 \&$ Child16-17 $=1 \quad 0.90$

$(\mathbf{N}=3538)$

0.89

$(\mathbf{N}=64,758)$

Note: The upper age limits of women in each group are: $41,45,48$, 52 , and 57

Number of observations in parentheses

are higher in the group who gets a child or whose child make a transition into a higher age group. An exception is the group with the oldest children where there is no significant difference in the transition rates between the groups. Since we do not know the exact age of the children but only the number of children in a certain age group, this essentially means that we look at women who has a new child (new born) or whose child reaches the lowest age in each group $(4,7,11,15$, or 16 years old). We condition on that there are no children in the household in this specific age group in period $t-1$.

An age restriction is imposed for all women to ensure that they are in a reasonable age in order to have a child in a certain age group; women should not have been older than 41 years when the child was born. This means that when looking at selfemployment transitions among women with a child that turns 4 , the upper age limit is set to 45 , when the child turns 7 the age limit is 48 , and so forth. If no upper age limit 
would have been imposed, the share with no children in this particular age groups would have been much higher.

\section{Results}

\subsection{Main results}

Our main results are presented in Table 4. Columns one and three present the results from the pooled cross-sectional models. In column one, the results from the linear probability model are presented and in column three the results from the logit model are presented. In columns two and four, the results from the corresponding panel data models are presented.

In all regressions we find a positive association between having children in the youngest age group and self-employment. The linear probability model indicates that each additional child in the age range $0-3$ increases the self-employment probability by $0.06 \%$ points. The estimate in the panel data model with individual fixed effects is also positive and significant and slightly larger; the self-employment probability increases with $0.1 \%$ points for each additional child in the youngest age group. This is a very small effect which is caused by that self-employment entry is a rare event, in

Table 4 Probability of self-employment among women (2004-2008)

\begin{tabular}{|c|c|c|c|c|}
\hline & $\begin{array}{l}\text { Pooled } \\
\text { cross-sections }\end{array}$ & Panel data & $\begin{array}{l}\text { Pooled } \\
\text { cross-sections }\end{array}$ & Panel data \\
\hline & $\begin{array}{l}\text { Linear probability } \\
\text { model }\end{array}$ & $\begin{array}{l}\text { Linear probability } \\
\text { model with } \\
\text { individual } \\
\text { fixed effects }\end{array}$ & $\begin{array}{l}\text { Logit model } \\
\text { (odds ratios) }\end{array}$ & $\begin{array}{l}\text { Conditional } \\
\text { fixed-effects } \\
\text { logit model } \\
\text { (odds ratios) }\end{array}$ \\
\hline \multicolumn{5}{|c|}{ Number of children } \\
\hline $0-3$ years & $\begin{array}{l}0.0006^{* * *} \\
(0.00012)\end{array}$ & $\begin{array}{l}0.0010 * * * \\
(0.00013)\end{array}$ & $\begin{array}{l}1.1447 * * * \\
(0.00449)\end{array}$ & $\begin{array}{l}1.1364 * * * \\
(0.01483)\end{array}$ \\
\hline $4-6$ years & $\begin{array}{l}0.0016 * * * \\
(0.00016)\end{array}$ & $\begin{array}{l}0.0015 * * * \\
(0.00015)\end{array}$ & $\begin{array}{l}1.1043 * * * \\
(0.00487)\end{array}$ & $\begin{array}{l}1.0874 * * * \\
(0.01573)\end{array}$ \\
\hline $7-10$ years & $\begin{array}{l}0.0019 * * * \\
(0.00014)\end{array}$ & $\begin{array}{l}0.0018^{* * *} \\
(0.00014)\end{array}$ & $\begin{array}{l}1.0735 * * * \\
(0.00376)\end{array}$ & $\begin{array}{l}1.0767 * * * \\
(0.01451)\end{array}$ \\
\hline $11-15$ years & $\begin{array}{l}0.0013 * * * \\
(0.00010)\end{array}$ & $\begin{array}{l}0.0020 * * * \\
(0.00011)\end{array}$ & $\begin{array}{l}1.0171 * * * \\
(0.00275)\end{array}$ & $\begin{array}{l}1.0701 * * * \\
(0.01230)\end{array}$ \\
\hline 16-17 years & $\begin{array}{l}0.0008^{* * *} \\
(0.00014)\end{array}$ & $\begin{array}{l}0.0013 * * * \\
(0.00011)\end{array}$ & $\begin{array}{l}0.9133 * * * \\
(0.00400)\end{array}$ & $\begin{array}{l}0.9739 * * \\
(0.01194)\end{array}$ \\
\hline Observations & $14,389,505$ & $14,389,505$ & $14,389,505$ & 582,627 \\
\hline$R^{2}$ & 0.015 & 0.001 & & \\
\hline
\end{tabular}

Notes: The cross-sectional model includes controls for: age, age squared, married, education, industry (11 groups), country of birth (11 groups), county of residence (21), and year (5 years). The panel data models do not include controls for year and country of birth 
particular since we look at year-to-year changes. It is, however, still interesting to see that the estimates are significantly different from 0 .

The results from the logit models lead to the same qualitative conclusion, although when the odds ratios are presented the interpretation is made in terms of how much, expressed in percent, the presence of children in a certain age group affects the odds of being (or becoming) self-employed. The conditional fixed-effect logit model also yields significant estimates, although this regression is based on substantially fewer observations.

Both logit models indicate that effect of children on self-employment decreases with the age of the children. This is consistent with the idea that the demand for selfemployment as a way to balance work and family is largest when the children are young and household and child care responsibilities are most demanding and decreases when the children grow older.

The reason for why both cross-sectional and panel data models have been estimated is that there might be a problem of reversed causality (Noseleit 2014a). Although, the main focus of this paper is not to establish causality between the number, or the presence, of children in the household and self-employment, we use panel data to control for unobserved heterogeneity across individuals. It is reassuring that Noseleit (2014a), who uses an instrumental variable approach, only finds evidence of there being a causal relationship between fertility and self-employment and not the other way around.

In the regression analysis, self-employment is compared to the probability of all other labor market states; wage employment as well as different types of nonemployment. In a multinomial logit model, the choice between self-employment and wage employment, as well as the choice between self-employment and nonemployment can be analyzed. To do this, self-employment is chosen to be the reference category. The results are presented in Table A1 in the Appendix. We see that the presence of children in all age groups, except the oldest, decreases the probability of wage employment compared to self-employment. Having children in the youngest age group increases the probability of being in non-employment compared to self-employment, a result that could be expected since non-employment includes women on parental leave. The presence of children in all other age groups decreases the probability of non-employment compared to self-employment.

We have estimated the corresponding logit models for men. These results are presented in Table A2 in the Appendix. We find a positive correlation between the number of young children and the probability of being self-employed also for men. However, the impact of an additional child is smaller if the children are very young ( $0-3$ years) and stronger if the children are older. This could mean that fathers do not choose self-employment when the need to be caring for the children is the highest which seems to be the case for mothers.

\subsection{Heterogeneous effects by educational level}

It has been argued in previous studies (see, e.g., Hundley 2000) that professionals and workers in managerial positions do not need to choose self-employment in order to achieve flexibility and to facilitate the combination of work and family. Many wage-earning jobs in the modern labor market are flexible with respect to where and 
when the work is performed. This idea is tested by estimating regressions separately for three educational groups: (1) primary school or upper secondary 2 years or less, (2) upper secondary more than 2 years or higher education less than 3 years, and (3) higher education 3 years or more or postgraduate education. We would expect to find most professionals and workers in managerial positions in the group with the highest educational level and hence expect the effect of children on self-employment to be non-existent or at least weakest in this group. The results are presented in Table 5 and from the linear probability model we find that there is a positive association between the number of young children and self-employment probabilities in all educational groups. ${ }^{5}$ Even for women with the highest level of education, each additional child in the youngest age group has a positive and significant impact on the probability of being self-employed. In the fixed-effects regressions the estimates of children in the youngest age group are about the same for all educational groups. Hence, it does not appear to be the case that only low-educated women choose self-employment as an alternative employment form while the children are young.

\section{Interpreting the results}

Our results suggest that self-employment probabilities among women increase with the number of children and that the effect is largest when the children are young. This is consistent with the results in previous studies and supports the hypothesis that women with more child care, and hence in many cases more household responsibilities, are more likely to choose self-employment to balance work and family. Previous studies using time-use data have found that self-employed women spend more time on household work and less time on market work than wage-earning women do, which also supports the idea that women chose self-employment to balance work and family.

But should the results for Sweden be interpreted in the same way? The remainder of the paper discusses two possible interpretations of our results. Do women in Sweden chose self-employment to balance work and family in spite of the institutions in place on the labor market which are built up and developed in order to facilitate the combination of work and family? Or, is it the case that mothers of young children who choose self-employment in fact are women who have very strong preferences for market work? Self-employment could then be a way for these women to avoid reducing time spent on market work to the extent they would have needed to do if they would have been employed as wage earners.

We will not be able to fully separate between these two interpretations; choosing self-employment to better balance work and family commitments or choosing selfemployment in order to still be active on the labor market when the children are young. To be able to say something we first look at some time-use data for Sweden. Second, we use information from administrative registers and look at the number of days of parental leave. If women choose self-employment to balance work and family we would expect them to spend less time on market work and more time on

\footnotetext{
${ }^{5}$ These models have also been estimated using a logit model. The results are not presented here but are available from the author upon request. The main results are invariant to the choice of model.
} 


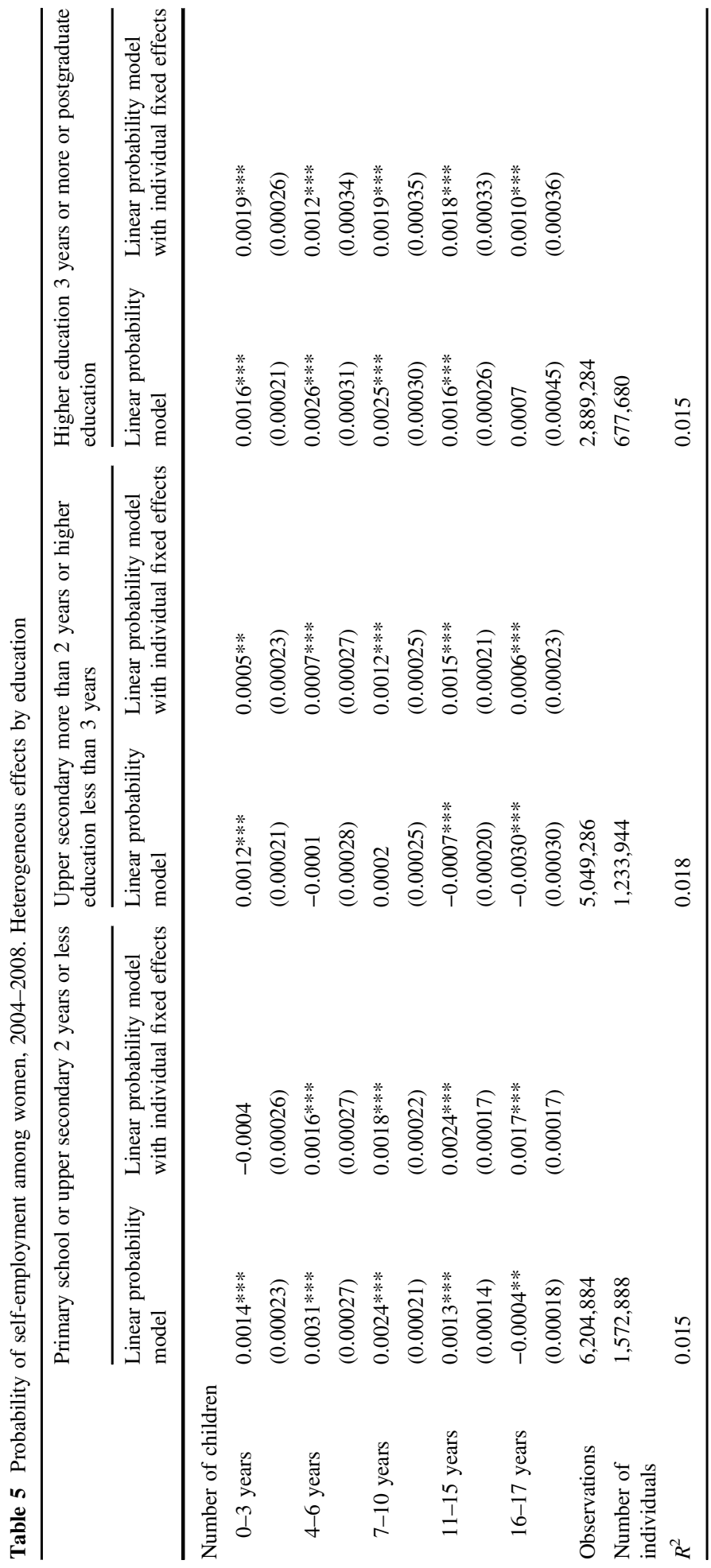


household work compared to wage-earning women. We also would expect them to take more days of parental leave. On the other hand, if it is women with strong preferences for market work that chose self-employment while the children are young we would expect the opposite: they spend more time on market work and less time on household work compared to wage-earning women and they will take fewer days of parental leave compared to wage earners.

One caveat to this analysis is that we do not have micro data on the time use of the individuals included in the administrative data source that is used to estimate selfemployment probabilities. We will therefore rely on some secondary sources with information on the time use of the self-employed and a regression analysis of a sample that includes only a small number of self-employed women (the Swedish Level-of-Living Survey).

\subsection{Time use among self-employed men and women in Sweden}

Previous studies for the United States, Australia, and Spain reveal that self-employed women spend less time on market work than wage-earning women. Descriptive statistics from the HETUS also show that in most countries wage-earning women spend more time on market work than self-employed women (see Fig. 1). According to this data, this is also the case in Sweden but the difference is smaller than in most other countries.

The evidence on time use of self-employed men and women in Sweden are scarce but at least two studies report that self-employed women spend more, or as much, time on market work as wage-earning women. Average weekly hours of market work based on different data sources are summarized in Table 6. Mångs (2013) report that self-employed women with children 0-3 years of age spend on average $37.8 \mathrm{~h}$ per week on market work and wage-earning women spend $35.9 \mathrm{~h}$ per week on market work. These results are based on a survey and the sample of self-employed is strongly selected. ${ }^{6}$ Johansson Sevä and Öun (2014) report that self-employed women with employees spend on average $45.8 \mathrm{~h}$ per week on market work and wage-earning women spend on average $38.3 \mathrm{~h}$ on market work. Self-employed women without employees spend about the same time on market work as wage-earning women. From the Swedish Level of Living Survey in 2000, we also see that self-employed women spend more time on market work than wage-earning women. The sample of self-employed women is however small in this survey and the average weekly working time is only based on 84 individuals. Data for Sweden from the HETUS show that self-employed women spend slightly less time on market work but the difference, $1.4 \mathrm{~h} /$ week, is smaller than in many other countries (https://www.h2.scb. se/tus/tus/). For men, all data sources show that self-employed men spend more time on market work than wage-earning men.

In previous studies it has also been found that self-employed women spend more time on household work than wage-earning women. The existing evidence for Sweden reveals that there are small differences in time spent on household work between wage-earning and self-employed women. Again, the HETUS show that in

\footnotetext{
6 Workers with an annual income below 100,000 SEK are excluded. Combiners, i.e., self-employed who also have had an income from wage employment during the year, are also excluded.
} 


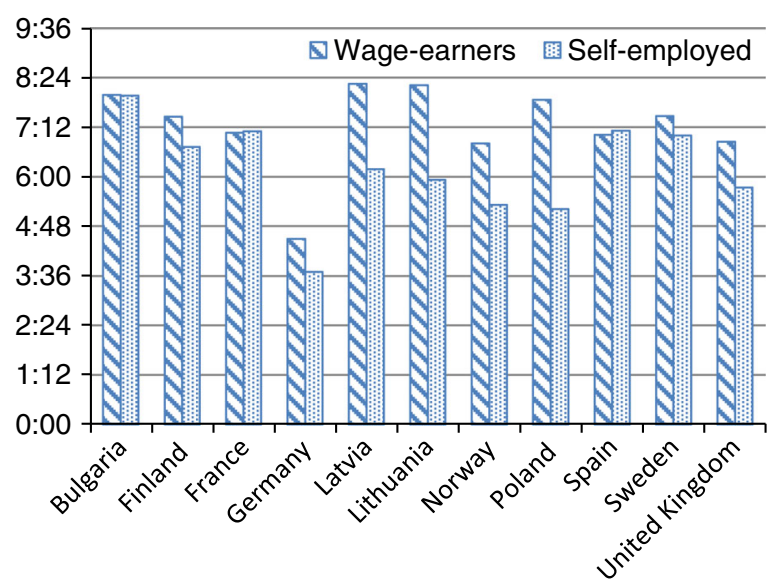

Fig. 1 Time spent during an ordinary work day on market work. Source: The HETUS

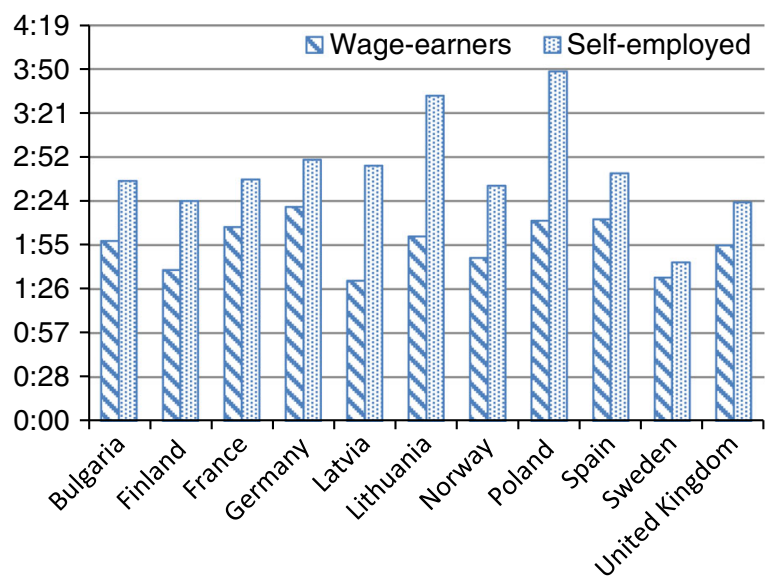

Fig. 2 Time spent during an ordinary work day on household work. Source: The HETUS

most countries self-employed women spend substantially more time on household work than wage-earning women do. But the difference is small in Sweden (see Fig. 2). In Table 6 we have also summarized what is known about time spent on household work based on data for Sweden. Even though the descriptive statistics on time spent on market work and household work presented here in no way are conclusive, it could still be argued that it is not apparent that Swedish women choose self-employment when the children are young to spend less time on market work and more time on household responsibilities.

Using individual data from the Level of Living Survey for year 2000, a multivariate analysis of time spent on market and household work is performed and the results are presented in Table 7 . Even though there are few individuals, in particular women, who are self-employed in this data we still find significant differences 


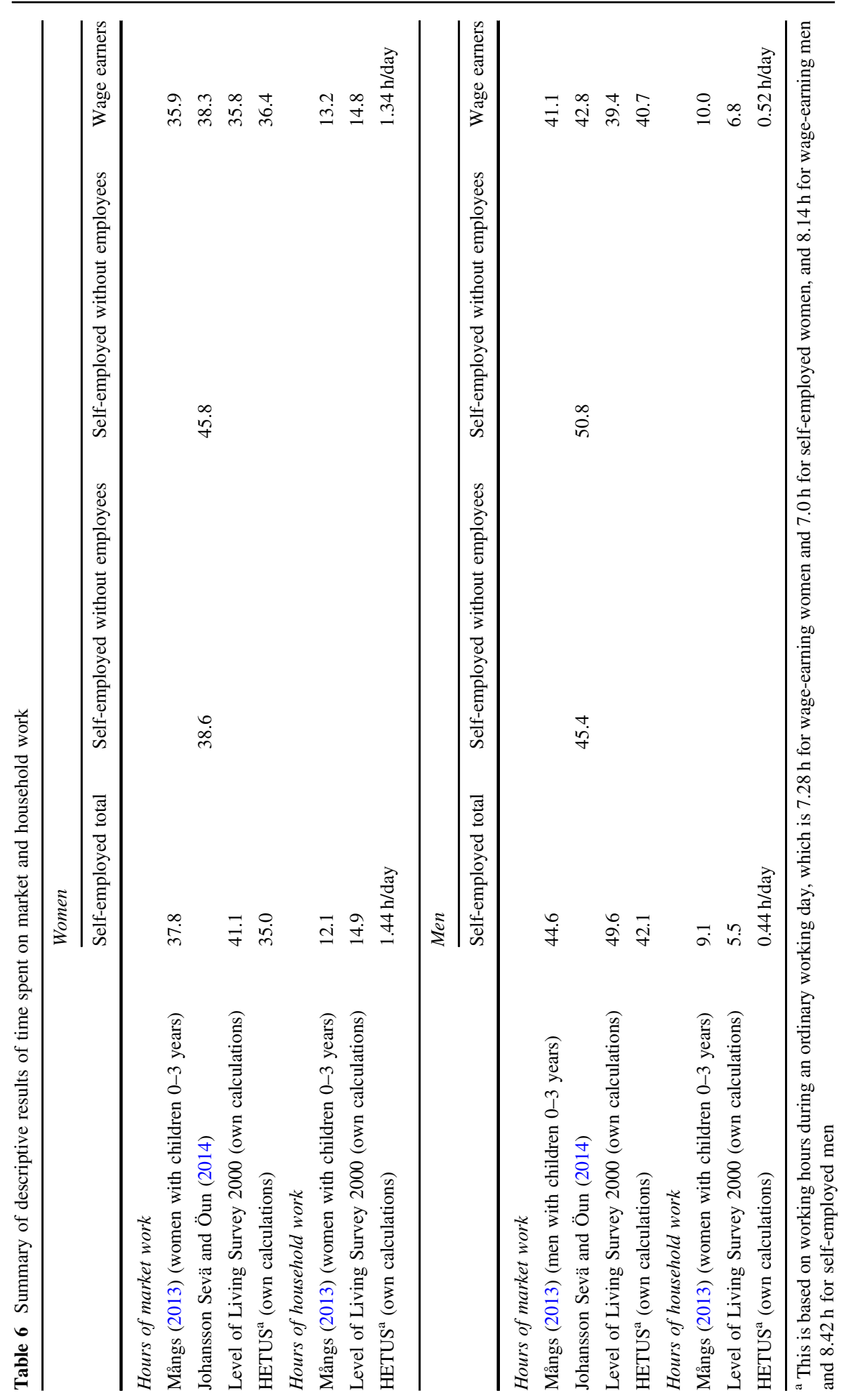


Table 7 Regression analyzes for time spent on market and household work, Level of Living Survey 2000, women

$\begin{array}{llll}\begin{array}{l}\text { Hours of } \\ \text { market work }\end{array} & \begin{array}{l}\text { Hours of } \\ \text { market work }\end{array} & \begin{array}{l}\text { Hours of } \\ \text { house work }\end{array} & \begin{array}{l}\text { Hours of } \\ \text { house work }\end{array}\end{array}$

\section{Women}

Wage earner

Self-employed, all

Self-employed, without employees

Self-employed, with employees

Partner wage earner

Partner self-employed

Partner other status

Constant

Observations

$R^{2}$

Men

Wage earner

Self-employed, all

$10.520 * * *$

(0.923)

Self-employed, without employees

Self-employed, with employees

\section{Ref.}

$-1.412 * *$

(0.670)

$-0.497$

(0.680)

$38.311 * * *$

(1.092)

1556

0.097

$4.959 * *$
$(2.023)$
$7.334 * * *$
$(2.143)$

Ref.

$-1.446 * *$

(0.676)

$-0.505$

(0.681)

$38.328 * * *$

(1.089)

1556

0.098

Partner wage earner

Partner self-employed

Partner other status

Constant

Observations

$R^{2}$
Ref.

Ref.

$-0.960$

(0.941)

$$
\begin{aligned}
& -1.478 \\
& (1.280) \\
& -0.424 \\
& (1.295)
\end{aligned}
$$

Ref.

$2.013 * * *$

$1.995 * * *$

(0.677)

(0.678)

$-2.088 * * *$

$-2.091 * * *$

(0.748)

(0.748)

$11.225^{* * * *}$

$11.244 * * *$

(1.133)

1318

1318

0.141

0.140

$-1.290 * * *$

(0.417)

$8.403 * * *$

(1.526)

$12.402 * * *$

(1.032)

$-2.979 * *$
$-2.710 * *$

(1.335)

$-0.580$

(0.425)

$40.735 * * *$

(0.695)

1764

0.241
$-1.946^{* * *}$

(0.514)

$-0.728$

(0.595)

0.257

(0.661)

(0.666)

$-0.063$

$-0.050$

(0.308)

40.627 ***

(0.702)

1764

0.232

(0.308)

$6.744 * * *$

$6.686^{* * *}$

(0.793)

1398

Note: All models include controls for: number of young children (0-9 years), having a partner (married/ cohabitating), age, education, and region. Robust standard errors in parentheses

$* * * p<0.01, * * p<0.05, * p<0.1$

regarding time spent on market work: self-employed women spend on average about $6 \mathrm{~h}$ more on market work than wage-earning women. We also find that self-employed both with and without employees spend more time on market work than wage- 
earning women but the differences are larger between wage earners and selfemployed with employees. We find no significant differences with respect to time spent on housework. The pattern for men is very similar: the self-employed spend more time on market work than wage earners. Here we do, however, also find that self-employed men, in particular those without employees, spend significantly less time on household work than wage-earning men.

It is also interesting to note that the employment status of the partner has a significant impact on the time spent on market work. For both women and men, having a self-employed spouse decreases the time spent on market work by about $1.4 \mathrm{~h}$ for women and by almost $3 \mathrm{~h}$ per week for men. Having a self-employed spouse increases the time spent on household work for women, but for men having a self-employed spouse have no significant effect on time spent on household work.

\subsection{Parental leave among wage earners and self-employed}

The Swedish parental leave system is both very generous and rather flexible. For each child, the parents are assigned 480 days. During 390 days, the replacement rate is about $80 \%$ of their previous earnings up to a certain ceiling. During the remaining 90 days the parents receive a fixed smaller amount. The parents can divide the number of days between them as they please but 60 days are assigned to each of the parent individually and cannot be transferred to the other. Each week one can be on parental for a maximum of 7 days, but if one chooses, for example, 5 days the length of the total parental leave period will be longer. It is possible to combine work with parental leave. One could, e.g., work 3 days a week and be on parental leave for 2 days.

To analyze differences in parental leave between self-employed and wage earners, we use the same register data as in the main analysis and add information on total number of days of parental leave during the year. A drawback of the data is that there is no information about when during the year the parental leave days were used. To be able to compare self-employed and wage earners it is assumed that the distribution of child births across the year is the same for wage earners and selfemployed since the total number of days taken during a year will depend on when the children are born. If a child is born on 1 January, it is possible for the parents to have 365 days of parental leave during the year, while if the child is born on 31 December, one could have 1 , or possibly 0 , days of parental leave. Second, when doing this the sample is restricted to births of the first child, i.e., the sample is conditioned on that there are no children living in the household in period $t-1$ while there is at least one child aged 0-3 living in the household in period $t$. Here the groups of self-employed are divided into those with an unincorporated firm and those with an incorporated firm. The former group is treated as self-employed in the social security system, while the latter group is treated as employees since they are employed in their own firm. Looking at sample means for the three groups: wage earners, self-employed with an unincorporated firm, and self-employed with an incorporated firm, we find that the difference between the groups in average number of days of parental leave are small but there is a larger spread in the number of days among self-employed with an unincorporated firm. Drawing 
histograms for the distribution of number of days in parental leave where each bin are 30 days, it is clear that the share among self-employed (with an unincorporated firm) who takes 30 days or less are higher compared to the other groups (see Fig. 3).

To investigate this further, a number of different regressions are estimated. In the first one we look at the association between self-employment and the probability of taking zero days of parental leave conditional on that there were no children living in the household in period $t-1$ and that there is at least one child in the age range $0-3$ years in period $t$. In most cases, this means that the women have become a (biological) mother but there could also be other situations. For example, if a woman has no children of her own in period $t-1$ and then marry a spouse who has children of his/her own this would appear in the data as the women have had a child, although it is not her biological child. This is not likely to be very common and we have no reason to believe that it is more common among self-employed women than among wage-earning women. In either case, this would be a situation where it is natural that the woman does not take any days of parental leave. In the second regression the probability of taking less than 30 days of parental leave is estimated, in the third regression the dependent variable is total net days of parental leave during a year, and in the fourth regression the same dependent variable is used but those who have zero days of parental leave are excluded.

The results of the regression analysis are presented in Table 8 , and focusing on self-employed with unincorporated firms we see that self-employed women have a $4.6 \%$ points higher probability of taking zero days of parental leave during the year and a $3.3 \%$ points higher probability of taking less than 30 days of parental leave. The third specification shows that there is no significant difference in net number of days of parental leave during the year, but when all women who take zero days of parental leave are excluded (column four) we find that self-employed take almost 5 more days of parental leave than wage earners do.

These results suggest that the group of self-employed is very heterogeneous; some take no or very few days of parental leave while others take more parental leave than the average wage earner. Also using Swedish register data, Anxo and Ericson (2015) find that self-employed women use on average 46 fewer days of parental leave than female wage earners and that self-employed men use on average 27 fewer days of parental leave than male wage earners.

\section{Summary and conclusions}

Previous studies have found a positive correlation between the presence of children in the household and self-employment probabilities among women. This has been interpreted as evidence of women choosing self-employment to balance work and family. Related studies using time-use data find that self-employed women spend more time on household work than wage-earning women and less time on market work.

There are reasons to believe that Swedish women do not choose self-employment in order to achieve more flexibility and to facilitate the combination of work and family. There are several institutions in place in the Swedish labor market with the 


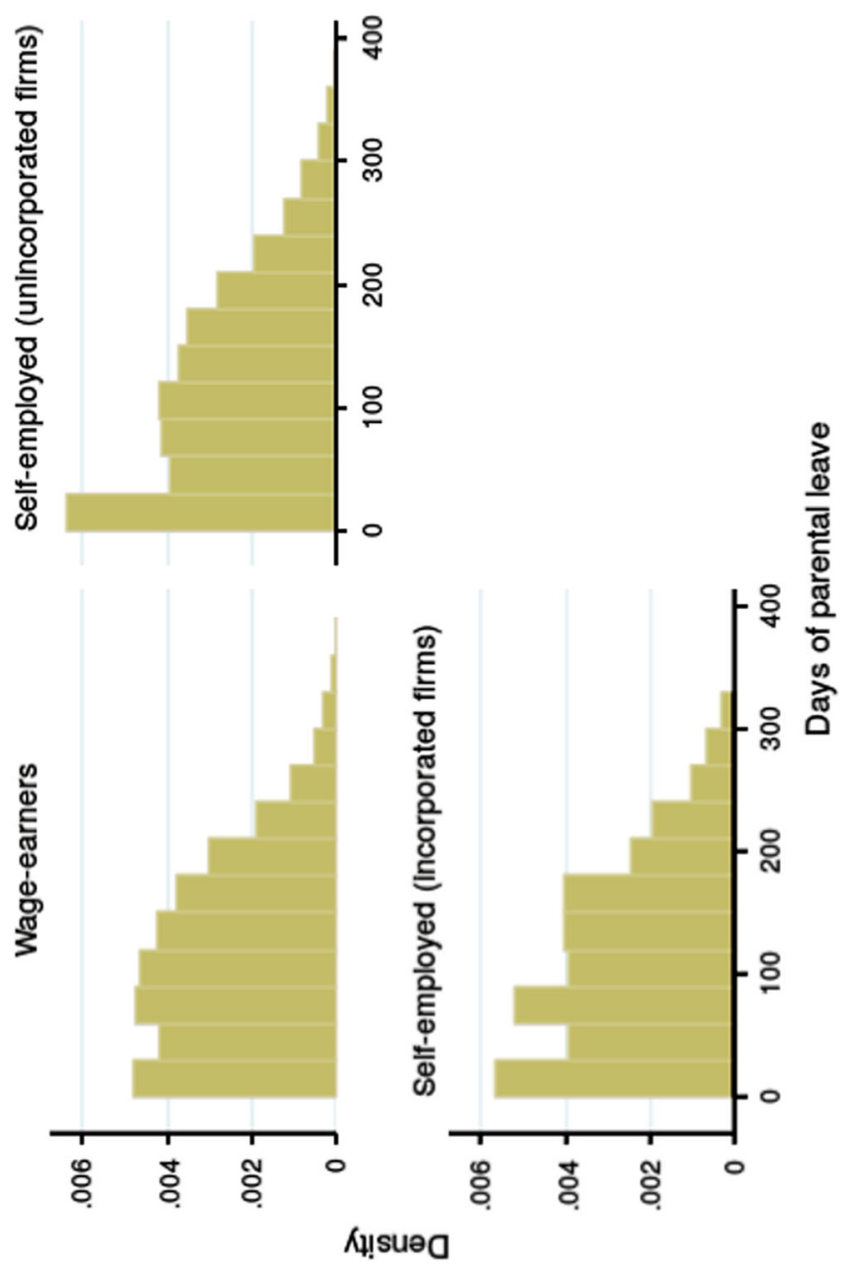

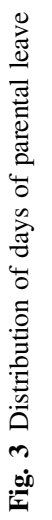


Table 8 Days of parental leave for women with no children in the household in period $t-1$ and at least one child in the age range $0-3$ in period $t$

\begin{tabular}{lllll}
\hline & $\begin{array}{l}\text { Number of } \\
\text { days of } \\
\text { parental leave }\end{array}$ & $\begin{array}{l}\text { Fewer than } \\
\text { 30 days of } \\
\text { parental leave }\end{array}$ & $\begin{array}{l}\text { Number of } \\
\text { days of } \\
\text { parental leave }\end{array}$ & $\begin{array}{l}\text { Number of } \\
\text { days of parental } \\
\text { leave if greater } \\
\text { than 0 }\end{array}$ \\
\hline Wage earners & Ref. & Ref. & Ref. & $\begin{array}{l}\text { Ref. } \\
\text { Self-employed (unincorporated firm) }\end{array}$ \\
$\begin{array}{llll}0.0463 * * * \\
\text { Self-employed (incorporated firm) }\end{array}$ & $0.0217 * *$ & $0.0327 * * *$ & -1.3049 & $4.9650 * *$ \\
& $(0.00843)$ & $(0.01165)$ & $(2.32602)$ & $(2.28654)$ \\
Additional controls & Yes & Yes & Yes & Yes \\
Number of observations & 153,254 & 153,254 & 153,254 & 144,250 \\
$R^{2}$ & 0.017 & 0.009 & 0.020 & 0.022 \\
\hline
\end{tabular}

Note: All models include controls for: number of children 0-3 years, age, age squared, married, education, industry (11 groups), country of birth (11 groups), county of residence (21), and year (5 years)

purpose of achieving this: generous parental leave system, easy access to public child care, and the right of parents to work part time until the child turns 8. Also the fact that mothers and fathers share child care and household responsibilities more equally than in many other countries suggests that mothers (and fathers) of young children might not have a very high demand for self-employment, at least not as a way to combine work and family.

The results presented in this paper do, however, point toward that Swedish mothers with young children are more likely to choose self-employment than other groups of women. This result is also found in panel data models where unobserved individual heterogeneity is controlled for, i.e., when it is taken into account that those who choose self-employment might differ from those in other labor market states in some systematic way regarding preferences for family formation and family size. Using time-use data it is found that self-employed women spend as much, or more, time on market work than wage-earning women. This result differs from what has been found for other countries. From analyzing parental leave use among wage earners and self-employed, it is concluded that the group of self-employed appears to be very heterogeneous; self-employed mothers are more likely to take no, or very short, parental leave even when the children are very young, but among those who do take some parental leave self-employed mothers take on average more days of parental leave than wage-earning mothers.

Looking at OECD data we see that the female self-employment share is lower in countries like Sweden and other Scandinavian countries compared to, e.g., the United Kingdom or Southern European countries like Italy, Spain, and Portugal. However, the US stands out with a relatively low share of women in self-employment (OECD 2016). Using data from the European Social Survey, Noseleit (2014b) compares female selfemployment rates across countries and analyze how it is related to child care availability. He finds a negative relationship; the female self-employment rate is lower in countries with better child care provision. 
The results presented in the present paper adds to previous findings from other countries but also to cross-country comparisons. We find that, in spite of generous child care provision, mothers of young children living in Sweden are more likely to be self-employed compared to being wage earners. The results from a multinomial logit model also reveal that women with children between 4 and 15 years of age are more likely to be self-employed compared to be in nonemployment.

A problem with making cross-country comparisons of the female self-employment rate is that in most cases all women are included in this measure. If one were to calculate the self-employment rate among mothers with dependent children it is possible that we would find smaller differences between countries. The results presented in this paper points toward this. When looking at the overall female selfemployment rate it is possible that cross-country differences mostly could be attributed to differences in the self-employment rate among women without dependent children. It would be very interesting if these questions could be addressed in a future study.

Acknowledgments The author gratefully acknowledges financial support from the Swedish Research Council (VR).

\section{Compliance with ethical standards}

Conflict of interest The author declares that she has no conflict of interest.

\section{Appendix}

Table A1 Probability of selfemployment women, 2004-2008 (multinomial logit model; odds ratios)

\begin{tabular}{llll}
\hline & $\begin{array}{l}\text { Self-employed } \\
\text { reference group }\end{array}$ & Wage earner & $\begin{array}{l}\text { Non- } \\
\text { employment }\end{array}$ \\
\hline Number of children & & \\
0-3 years & $0.8132 * * *$ & $1.2623 * * *$ \\
& $(0.00321)$ & $(0.00541)$ \\
4-6 years & $0.8901 * * *$ & $0.9387 * * *$ \\
& $(0.00394)$ & $(0.00468)$ \\
$7-10$ years & $0.9190 * * *$ & $0.9305 * * *$ \\
& $(0.00323)$ & $(0.00371)$ \\
$11-15$ years & $0.9844 * * *$ & $0.8986 * * *$ \\
& $(0.00266)$ & $(0.00275)$ \\
$16-17$ years & $1.0772 * * *$ & $1.1491 * * *$ \\
& $(0.00473)$ & $(0.00542)$ \\
Observations & $14,389,505$ & - \\
\hline
\end{tabular}

Note: Robust standard errors in parentheses. $* * * p<0.01, * * p<0.05$, ${ }^{*} p<0.1$. The model also includes controls for: age, age squared, marital status, education, region of birth, county of residence, and year dummies 
Table A2 Probability of self-employment among employed men (2004-2008)

\begin{tabular}{|c|c|c|c|c|}
\hline & $\begin{array}{l}\text { Pooled cross- } \\
\text { sections }\end{array}$ & Panel data & $\begin{array}{l}\text { Pooled cross- } \\
\text { sections }\end{array}$ & Panel data \\
\hline & $\begin{array}{l}\text { Linear } \\
\text { probability } \\
\text { model }\end{array}$ & $\begin{array}{l}\text { Linear probability } \\
\text { model with individual } \\
\text { fixed effects }\end{array}$ & $\begin{array}{l}\text { Logit model } \\
\text { (relative risk } \\
\text { ratios) }\end{array}$ & $\begin{array}{l}\text { Conditional fixed- } \\
\text { effects logit model } \\
\text { (relative risk ratios) }\end{array}$ \\
\hline \multicolumn{5}{|c|}{ Number of children } \\
\hline $0-3$ years & $\begin{array}{l}0.0063 * * * \\
(0.00020)\end{array}$ & $\begin{array}{l}0.0013 * * * \\
(0.00018)\end{array}$ & $\begin{array}{l}1.1846 * * * \\
(0.00296)\end{array}$ & $\begin{array}{l}1.0442 * * * \\
(0.00883)\end{array}$ \\
\hline $4-6$ years & $\begin{array}{l}0.0086 * * * \\
(0.00027)\end{array}$ & $\begin{array}{l}0.0030 * * * \\
(0.00021)\end{array}$ & $\begin{array}{l}1.1440 * * * \\
(0.00335)\end{array}$ & $\begin{array}{l}1.0713 * * * \\
(0.01039)\end{array}$ \\
\hline $7-10$ years & $\begin{array}{l}0.0096 * * * \\
(0.00023)\end{array}$ & $\begin{array}{l}0.0035 * * * \\
(0.00019)\end{array}$ & $\begin{array}{l}1.1169 * * * \\
(0.00263)\end{array}$ & $\begin{array}{l}1.0623 * * * \\
(0.00963)\end{array}$ \\
\hline $11-15$ years & $\begin{array}{l}0.0088 * * * \\
(0.00017)\end{array}$ & $\begin{array}{l}0.0032 * * * \\
(0.00016)\end{array}$ & $\begin{array}{l}1.0765 * * * \\
(0.00195)\end{array}$ & $\begin{array}{l}1.0300 * * * \\
(0.00815)\end{array}$ \\
\hline 16-17 years & $\begin{array}{l}0.0072 * * * \\
(0.00023)\end{array}$ & $\begin{array}{l}0.0030 * * * \\
(0.00016)\end{array}$ & $\begin{array}{l}1.0008 \\
(0.00298)\end{array}$ & $\begin{array}{l}0.9800 * * \\
(0.00888)\end{array}$ \\
\hline Observations & $14,856,878$ & $14,856,878$ & $14,856,878$ & $1,152,711$ \\
\hline$R^{2}$ & 0.038 & 0.002 & & \\
\hline
\end{tabular}

\section{References}

Angrist, J. D., \& Evans, W. N. (1998). Children and their parents' labor supply: evidence from exogenous variations in family size. American Economic Review, 88(3), 450-477.

Anxo, D., \& Ericson, T. (2015). Self-employment and parental leave. Small Business Economics, doi: $10.1007 / \mathrm{s} 11187-015-9669-6$.

Blanchflower, D. G. (2000). Self-employment in OECD countries. Labour Economics, 7(5), 471-505.

Boden, R. J. (1996). Gender and self-employment selection: An empirical assessment. Journal of SocioEconomics, 25(6), 671-682.

Boden, R. J. (1999). Flexible working hours, family responsibilities, and female self-employment. American Journal of Economics and Sociology, 58(1), 71-83.

Broussard, N. H., Chami, R., \& Hess, G. D. (2015). (Why) do self-employed parents have more children? Review of Economics of the Household, 13(2), 297-321.

Budig, M. J. (2006). Intersections on the road to self-employment: gender, family and occupational class. Social Forces, 84(4), 2223-2239.

Carr, D. (1996). Two paths to self-employment? Women's and men's self-employment in the United States, 1980. Work and Occupations, 23(1), 26-53.

Chamberlain, G. (1980). Analysis of covariance with qualitative data. Review of Economic Studies, 47(1), $225-238$.

Chamberlain, G. (1984). Panel data. In Z. Griliches, \& M. Intriligator (Eds.), Handbook of econometrics, vol. 2. Amsterdam: Elsevier Science Publishers.

Craig, L., Powell, A., \& Cortis, N. (2012). Self-employment, work-family time and the gender division of labour. Work, employment and society. 26(5), 716-734.

Davis, S. J., \& Henrekson, M. (1999). Explaining national differences in the size and industry distribution of employment. Small Business Economics, 12(1), 59-83.

Fölster, S. (2002). Do lower taxes stimulate self-employment?. Small Business Economics, 19(2), 135-145. 
Gimenez-Nadal, J., Molina, A., \& Ortega, R. (2012). Self-employed mothers and the work-family conflict. Applied Economics, 44(17), 2133-2147.

Gurley-Calvez, T., Biehl, A., \& Harper, K. (2009). Time-use patterns and women entrepreneurship. American Economic Review: Papers and Proceedings, 99(2), 139-144.

Gutiérrez-Doménche, M. (2010). Parental employment and time with children in Spain. Review of Economics of the Household, 8, 371-391.

Hundley, G. (2000). Male/female earnings differences in self-employment: The effects of marriage, children, and the household division of labor. Industrial and Labor Relations Review, 54(1), 95-114.

Johansson Sevä, I., \& Öun, I. (2014). Self-employment as a strategy for dealing with the competing demands of work and family? The importance of family/lifestyle motives. Gender, Work and Organization, 22(3), 256-272.

Lombard, K.V. (2001). Female self-employment and demand for flexible, nonstandard work schedules. Economic Inquiry, 39(2), 214-237.

Maddala, G. S. (1987). Limited dependent variable models using panel data. Journal of Human Resources, 22(3), 307-338.

Mångs, A. (2013). Self-employment in Sweden: A gender perspective. Växjö, Sweden: Linnaeus University Press. Linnaeus University Dissertations No 146/213

Nordenmark, M., Vinberg, S., \& Strandh, M. (2012). Job control and demands, work-life balance and wellbeing amongPlease provide page range in the reference Nordenmark et al. (2012). self-employed men and women in Europe. Vulnerable Groups \& Inclusion, Vol. 3, doi: 10.3402/vgi.v3i0.18896.

Noseleit, F. (2014a). Female self-employment and children. Small Business Economics, 43(3), 549-569.

Noseleit, F. (2014b). The impact of childcare enrollment on women's selection into self-employment. Working Paper No. 2014/15, Maastricht School of Management.

OECD (2016). Self-employment rate. https://data.oecd.org/emp/self-employment-rate.htm. 20 April 2016.

Rønsen, M. (2014). Children and family: A barrier or an incentive to female self-employment in Norway. International Labour Review, 153(2), 337-349.

Torrini, R. (2005). Cross-country differences in self-employment rates: The role of institutions. Labour Economics, 12(5), 661-683.

Wellington, A. J. (2006). Self-employment: The new solution for balancing family and career? Labour Economics, 13(3), 357-386. 